\title{
Strong atmospheric chemistry feedback to climate warming from Arctic methane emissions
}

\author{
Ivar S. A. Isaksen, ${ }^{1,2}$ Michael Gauss, ${ }^{1,3}$ Gunnar Myhre, ${ }^{1,2}$ Katey M. Walter Anthony, ${ }^{4}$ \\ and Carolyn Ruppel ${ }^{5}$ \\ Received 13 April 2010; revised 4 November 2010; accepted 4 February 2011; published 20 April 2011.
}

[1] The magnitude and feedbacks of future methane release from the Arctic region are unknown. Despite limited documentation of potential future releases associated with thawing permafrost and degassing methane hydrates, the large potential for future methane releases calls for improved understanding of the interaction of a changing climate with processes in the Arctic and chemical feedbacks in the atmosphere. Here we apply a "state of the art" atmospheric chemistry transport model to show that large emissions of $\mathrm{CH}_{4}$ would likely have an unexpectedly large impact on the chemical composition of the atmosphere and on radiative forcing (RF). The indirect contribution to RF of additional methane emission is particularly important. It is shown that if global methane emissions were to increase by factors of 2.5 and 5.2 above current emissions, the indirect contributions to RF would be about $250 \%$ and $400 \%$, respectively, of the RF that can be attributed to directly emitted methane alone. Assuming several hypothetical scenarios of $\mathrm{CH}_{4}$ release associated with permafrost thaw, shallow marine hydrate degassing, and submarine landslides, we find a strong positive feedback on RF through atmospheric chemistry. In particular, the impact of $\mathrm{CH}_{4}$ is enhanced through increase of its lifetime, and of atmospheric abundances of ozone, stratospheric water vapor, and $\mathrm{CO}_{2}$ as a result of atmospheric chemical processes. Despite uncertainties in emission scenarios, our results provide a better understanding of the feedbacks in the atmospheric chemistry that would amplify climate warming.

Citation: Isaksen, I. S. A., M. Gauss, G. Myhre, K. M. Walter Anthony, and C. Ruppel (2011), Strong atmospheric chemistry feedback to climate warming from Arctic methane emissions, Global Biogeochem. Cycles, 25, GB2002, doi:10.1029/2010GB003845.

\section{Introduction}

[2] Methane $\left(\mathrm{CH}_{4}\right)$ is an important greenhouse gas with a radiative forcing (RF) of $0.48 \mathrm{Wm}^{-2}$, due to anthropogenic activity since preindustrial time [Forster et al., 2007], being second only to $\mathrm{CO}_{2}$ among the anthropogenic greenhouse gases. Its distribution and growth are well documented [Forster et al., 2007; Ramaswamy et al., 2001] showing a significant increase in atmospheric concentrations since preindustrial times. Analyses of ice core data for the last 650,000 years show that atmospheric $\mathrm{CH}_{4}$ concentrations varied from approximately $400 \mathrm{ppb}$ during glacial periods to approximately $700 \mathrm{ppb}$ during interglacial periods. The tro-

\footnotetext{
${ }^{1}$ Department of Geosciences, University of Oslo, Oslo, Norway.

${ }^{2}$ Center for International Climate and Environmental Research-Oslo, Oslo, Norway.

${ }^{3}$ Norwegian Meteorological Institute, Oslo, Norway.

${ }^{4}$ Water and Environmental Research Center, Institute of Northern Engineering and International Arctic Research, University of Alaska, Fairbanks, Alaska, USA.

${ }^{5}$ U.S. Geological Survey, Woods Hole, Massachusetts, USA.

Copyright 2011 by the American Geophysical Union. 0886-6236/11/2010GB003845
}

pospheric average concentration is currently about $1,800 \mathrm{ppb}$, representing an approximate 2.5 increase since preindustrial time. The atmospheric concentrations in 2005 correspond to an atmospheric burden of 4,900 $\mathrm{Tg} \mathrm{CH}_{4}\left(1 \mathrm{Tg}=10^{12} \mathrm{~g}\right)$. Observations since 1984, for which there are continuous measurements, show an increase in atmospheric abundances of $\mathrm{CH}_{4}$ by about $10 \%$. Growth rates have decreased significantly since the early 1990 s, but with pronounced interannual variations [Rigby et al., 2008].

[3] $\mathrm{CH}_{4}$ is a chemically active greenhouse gas, and its long-term distribution is affected by changes in both emissions and the atmospheric oxidation rate. Estimates of current global $\mathrm{CH}_{4}$ emissions are in the range 500 to $600 \mathrm{Tg} \mathrm{CH}_{4} \mathrm{yr}^{-1}$ [Denman et al., 2007].

[4] Atmospheric $\mathrm{CH}_{4}$ is removed through oxidation by the hydroxyl radical $(\mathrm{OH})$, mainly in the troposphere:

$$
\mathrm{CH}_{4}+\mathrm{OH} \rightarrow \mathrm{H}_{2} \mathrm{O}+\mathrm{CH}_{3}
$$

[5] A small fraction is also removed by surface deposition. In the stratosphere, where water vapor is in the range of only a few ppm, $\mathrm{CH}_{4}$ oxidation contributes to water vapor buildup. Since reaction (R1) also represents a significant 
loss path for $\mathrm{OH}$, additional $\mathrm{CH}_{4}$ emission will suppress $\mathrm{OH}$ and thereby increase the $\mathrm{CH}_{4}$ lifetime, implying further increases in atmospheric $\mathrm{CH}_{4}$ concentrations [Isaksen and Hov, 1987; Prather et al., 2001]. This represents a positive chemical feedback, with a feedback factor estimated to be about 1.4 (uncertainty range 1.3 to 1.7 ) for current atmospheric conditions [Prather et al., 2001]. The nonlinearity in the chemical system could result in a significantly enhanced feedback factor for large $\mathrm{CH}_{4}$ emissions causing large perturbations [Isaksen, 1988].

[6] The growth in atmospheric $\mathrm{CH}_{4}$ concentrations, a result of an imbalance between sources and sinks, observed over several decades, is reduced markedly during recent years [Dlugokencky et al., 2003]. For instance, estimates reported in IPCC AR4 give close to a balance (about $1 \mathrm{Tg}$ $\mathrm{CH}_{4} \mathrm{yr}^{-1}$ difference between emissions and loss) for the time period 2000 to 2005 [Denman et al., 2007], compared to $33 \mathrm{Tg} \mathrm{CH} \mathrm{yr}^{-1}$ during the 1980 s. Although there are no clear indications whether the changes in trends are due to stabilization in emissions or enhanced atmospheric loss through increased OH levels [Prather et al., 2001], Dlugokencky et al. [2003] point to a possible stabilization of emissions in recent decades. This could be a result of changes in emissions from anthropogenic sources and from wetlands [Bousquet et al., 2006]. However, analyses of atmospheric $\mathrm{CH}_{4}$ changes in 2007 indicate a renewed growth of $\mathrm{CH}_{4}$ [Rigby et al., 2008].

[7] Increased $\mathrm{CH}_{4}$ emissions affect climate in several ways: Directly through increased $\mathrm{CH}_{4}$ concentrations and indirectly through the chemical feedback on $\mathrm{CH}_{4}$ levels and through production of $\mathrm{O}_{3}$ and stratospheric $\mathrm{H}_{2} \mathrm{O}$. Furthermore, $\mathrm{CO}_{2}$ will increase since it is the end product of atmospheric $\mathrm{CH}_{4}$ oxidation. In the current atmosphere the indirect $\mathrm{RF}$ is approximately the same as the direct methane RF, taking into account the effect on its own lifetime, on ozone, and on stratospheric water vapor [Forster et al., 2007].

[8] In this study we use a global Chemical Transport Model (CTM), the Oslo CTM2 [Isaksen et al., 2005; Søvde et al., 2008], to estimate the impact of additional $\mathrm{CH}_{4}$ emissions on the atmospheric concentrations of the climate gases $\mathrm{CH}_{4}, \mathrm{O}_{3}$, stratospheric $\mathrm{H}_{2} \mathrm{O}$, and $\mathrm{CO}_{2}$, and on $\mathrm{RF}$ from these forcing agents. The study covers a wide range of hypothetical methane emission scenarios, up to about 5 times the current emission rate. Although there is no evidence supporting the higher emission in this range, we include them in order to demonstrate the particularly strong positive feedback in the chemical system from large methane releases and the general impact on atmospheric composition and on climate forcing.

[9] We further consider two potentially important natural sources of atmospheric $\mathrm{CH}_{4}$ in relation to the adopted scenarios: (1) Conversion of organic carbon to $\mathrm{CH}_{4}$, and release when permafrost thaws; and (2) release of $\mathrm{CH}_{4}$ hydrates in marine sediments. Earlier studies have demonstrated that large releases of $\mathrm{CH}_{4}$ from natural sources during warming events can have significant impacts on atmospheric $\mathrm{CH}_{4}$ levels and may have potential synergistic effects leading to increased and/or sustained global warming. Observed surface temperatures in recent years show significant warming, indicating Arctic warming of more than a factor 2 greater than the global mean value [Hansen et al., 2007]. Permafrost thawing could be more extensive than previously predicted [Camill, 2005; Osterkamp, 2005], with large potential for methane emission.

[10] Atmospheric $\mathrm{CH}_{4}$ has a global average atmospheric lifetime of approximately 8 to 10 years [Denman et al., 2007]. Thus, atmospheric composition changes initiated by methane emissions from Arctic warming depend critically on the time horizon of the $\mathrm{CH}_{4}$ releases from thawing permafrost and degassing from marine hydrates (centennial to millennium timescales).

[11] Our calculations are based on a range of hypothetical future emission scenarios for $\mathrm{CH}_{4}$. There are currently no studies that quantify large $\mathrm{CH}_{4}$ emission from permafrost thawing and destabilization of marine gas hydrates in the Arctic in a future warmer climate.

\section{2. $\mathrm{CH}_{4}$ Emissions From the Arctic Region}

[12] We consider two major sources of $\mathrm{CH}_{4}$ emissions from the warming Arctic: (1) Methane produced from microbial degradation of labile organic carbon that becomes bioavailable as permafrost thaws; and (2) methane released from gas hydrate deposits as they dissociate in response to climate warming. Thawing permafrost may also promote emissions from other methane sources in the Arctic, but the amount of methane that could potentially be produced by microbial processes in thawed soils or release of methane from gas hydrates far exceeds that associated with other Arctic sources. There is evidence that continuous permafrost is actively thawing in many circum-Arctic regions, both onshore and in the shallow offshore continental shelves [Rachold et al., 2007].

\subsection{Methane and Thawing Permafrost}

[13] Thawing of permafrost at a rate of $0.04-0.10 \mathrm{~m} \mathrm{yr}^{-1}$ has been observed in some terrestrial upland regions [Osterkamp, 2005], and it is shown that temperatures have increased at depths as great as 25 to $30 \mathrm{~m}$ below the surface at some locations in the Arctic during the last two decades [Isaksen et al., 2007; Osterkamp and Jorgenson, 2006]. Camill [2005] finds that if the current rate of temperature increase (which is at least twice that of the global mean temperature increase) continues at his sites in boreal peatlands in Arctic Canada, the permafrost will have disappeared by the end of this century. The observations at this measurement site are consistent with a warming of at least $7-8^{\circ} \mathrm{C}$ in a high- $\mathrm{CO}_{2}$-emission scenario.

[14] Northern soils sequester an estimated 1,672 Pg $(1 \mathrm{Pg}=1 \mathrm{e}+15 \mathrm{~g})$ of organic $\mathrm{C}, 88 \%$ of which is stored in perennially frozen ground [Tarnocai et al., 2009]. The yedoma ice complex within the continuous permafrost in Northern Siberia is of particular interest for understanding the interplay among thawing permafrost, organic carbon, and methane emissions. The yedoma complex consists of ice-rich frozen loess and loess-related sediments that cover approximately 1 million $\mathrm{km}^{2}$. These sediments have organic carbon content of approximately $27 \mathrm{~kg} \mathrm{C} / \mathrm{m}^{3}$ [Walter et al., 2006] and represent a large reservoir ( $450 \mathrm{Pg} \mathrm{C})$ of labile organic carbon [Zimov et al., 1997]. An additional $240 \mathrm{Pg} \mathrm{C}$ are sequestered in continuous permafrost in thick fluvial deltaic deposits. Thawing of this permafrost and particularly of the yedoma ice complex could produce large $\mathrm{CH}_{4}$ emissions via anaerobic degradation of the labile carbon, as 
demonstrated in laboratory incubations by Zimov et al. [1997]. In order to have sustained anaerobic conditions in thermokarsting soils, meltwater needs to be retained in the yedoma complex.

[15] Thermokarst lakes (lakes that have an underlying thaw bulb and that are widespread in some parts of the Arctic) are among the best places to study the potential release of $\mathrm{CH}_{4}$ during permafrost degradation. Plug and West [2009] consider thermokarst expansion rates of up to $8 \mathrm{~m}$ in a single year. A strong amplification of $\mathrm{CH}_{4}$ emissions from Arctic lakes due to thawing of permafrost has already been observed in response to ongoing climate warming. For instance, Walter et al. [2006] described significant increases $(\sim 60 \%)$ in $\mathrm{CH}_{4}$ emissions from North Siberian thermokarst lakes between 1974 and 2000, associated with a more moderate $(15 \%)$ increase in lake area during the same period. Calculations by Walter et al. [2007] suggest that $\sim 50 \mathrm{Pg} \mathrm{CH}_{4}$ will be released from Siberian thermokarst (thaw) lakes as yedoma permafrost thaws over a timescale of centuries to millennia. $\mathrm{CH}_{4}$ emission from lakes in other nonyedoma permafrost-dominated regions in the Arctic is also expected as thermokarst lakes form and expand in conjunction with warming and thawing of permafrost.

[16] The remainder of nonyedoma permafrost in the Arctic contains $\sim 1,000 \mathrm{Pg}$ C [Tarnocai et al., 2009]. Assuming that $10 \%$ of this permafrost will thaw beneath lakes and $17 \%$ of the $\mathrm{C}$ in the thawed permafrost will be converted to $\mathrm{CH}_{4}$, similar to the efficiency of $\mathrm{CH}_{4}$ production in yedoma, we estimate that $23 \mathrm{Pg} \mathrm{CH}_{4}$ can be released from nonyedoma thermokarst lakes. Together, thawing of yedoma and nonyedoma permafrost could thus release up to $73 \mathrm{Pg} \mathrm{CH}_{4}$ to the atmosphere.

[17] Several studies indicate that high-latitude wetlands have $\mathrm{CH}_{4}$ emissions that are sensitive to increased temperatures. For example, northern peatlands that experience permafrost thaw [Christensen et al., 2004; Wickland et al., 2006] have enhanced $\mathrm{CH}_{4}$ emissions. Due to uncertainties associated with future surface moisture and redox regimes, enhanced wetland emissions are not explicitly included as a methane source here.

[18] The $\mathrm{CH}_{4}$ emission rate and the magnitude of its accumulation in the atmosphere strongly depend on the rate of permafrost thaw. Under current assumptions of warming in the Arctic, permafrost thaw and $\mathrm{CH}_{4}$ release are likely to occur over timescales of centuries to millennia. In scenarios of more enhanced warming of the Arctic than considered in current climate models [IPCC, 2007] the timescale for $\mathrm{CH}_{4}$ release due to permafrost thawing could be shorter. Although the current global contribution from North Siberian thermokarst lake emissions of $\mathrm{CH}_{4}$ are small, Walter et al. [2006] indicate that these emissions have increased significantly $(\sim 60 \%)$ between 1974 and 2000 .

\subsection{Methane Hydrates}

[19] Gas hydrates (clathrates) are a solid, ice like form of mostly methane, which occur beneath and possibly within [Dallimore and Collett, 1995] onshore permafrost and also in subsea permafrost that persists in some high-latitude regions to water depths as great as $\sim 90 \mathrm{~m}$. Both permafrostassociated gas hydrates and the shallowest part of the deepwater marine gas hydrate system are susceptible to dissociation (breakdown to methane and water) under conditions of a warming Arctic climate.

[20] The most recent review of the numerous published estimates of the amount of methane sequestered in global gas hydrate deposits converges on a range of 3 to $40 \times 10^{15} \mathrm{~m}^{3}$ of methane [Boswell and Collett, 2011], which converts to a range of $\sim 1,600$ to $21,000 \mathrm{Pg} \mathrm{C}$. This consensus range brackets some older estimates $(3000 \mathrm{Pg} \mathrm{C}$ in the work of Buffett and Archer [2004]) and a recent estimate of 1,000 to $10,000 \mathrm{Pg} \mathrm{C}$ by Krey et al. [2009]. Based on the estimates by Soloviev et al. [1987], Shakhova et al. [2010a] conclude that one quarter of the Arctic ocean shelf contains $540 \mathrm{Pg}$ $\mathrm{CH}_{4}$ in gas hydrates. This yields an estimated $\sim 1,600 \mathrm{Pg} \mathrm{C}$ within gas hydrates associated with subsea permafrost on the Arctic Ocean continental shelves. It is important to note that the formerly terrestrial sediments on these very shallow shelves contain significant additional carbon in nonhydrate form. Like the carbon trapped in terrestrial permafrost, this additional carbon is subject to microbial degradation and $\mathrm{CO}_{2}$ and $\mathrm{CH}_{4}$ production as the subsea permafrost thaws.

[21] In the deep geologic past, $\mathrm{CH}_{4}$ releases from gas hydrates may have been triggered by, but also possibly exacerbated, the extreme warming event at $\sim 55$ Ma before present [Dickens et al., 1995, 1997; Lamarque et al., 2006; Renssen et al., 2004; Schmidt and Shindell, 2003]. In this study we estimate a range of potential future methane emissions from the various Arctic gas hydrate populations:

[22] 1. Subsea Permafrost: There is substantial evidence that subsea permafrost is undergoing rapid degradation at high northern latitudes [e.g., Rachold et al., 2007; Shakhova et al., 2005]. The current rate of subsea permafrost degradation is unknown, and acceleration in this degradation with recent changes in sea ice cover and thus ocean temperatures is expected, but not yet fully documented. Still, dissociation of methane hydrate that is currently capped by or contained within subsea permafrost is very likely occurring now [e.g., Shakhova et al., 2010b] and should increase as warming affects the ocean-atmosphere system. Methane released from these hydrates would be emitted into shallow seas where relatively little is likely to be oxidized before reaching the atmosphere. Shakhova et al. [2008] speculate that $50 \mathrm{Pg}$ $\mathrm{CH}_{4}$ could be released abruptly at any time from gas hydrates associated with subsea permafrost. Although there is no basis for estimating the rate of such a release, this value is used as a worst case scenario for the numerical model studies.

[23] 2. Methane hydrates in terrestrial permafrost near the top of the gas hydrate stability zone are unlikely to contribute significantly to the net methane flux from these deposits. A critical exception may be beneath deep thermokarst thaw bulbs, where the superposition of climate-induced surface warming and possible thaw bulb growth may so perturb temperatures near the top of the gas hydrate stability zone that methane hydrate at depths of only a few hundred meters might be susceptible to dissociation.

[24] 3. Deepwater marine hydrates: Most deepwater gas hydrates are unlikely to be a major source of atmospheric methane in climate scenarios that consider less than several millennia. Dissolution and oxidation are likely to strongly reduce the amount of methane that reaches the atmosphere once it is emitted at the seafloor. One exception is gas hydrate in continental margin sediments at pressure-temperature conditions close to the gas hydrate phase boundary. For 
example, contemporary climate warming may be triggering gas hydrate dissociation and methane emissions along the West Spitsbergen margin [Westbrook et al., 2009]. In that case, much of the methane is emitted rapidly and in bubble streams, meaning that significant amounts could reach the atmosphere. In other cases, oxidation and dissolution might be expected to prevent much methane from crossing the ocean-atmosphere interface. The numerical model studies presented here do not include a potential contribution from this population of potentially degrading gas hydrates.

[25] Submarine landslides associated with gas hydrates and/or underlying free gas are possible for $\mathrm{CH}_{4}$ release from marine sediments (e.g., discussion and references in the work of Archer [2007]). It is assumed that single landslides can release up to about $5 \mathrm{Pg} \mathrm{C}$ as $\mathrm{CH}_{4}$, based on estimates of past major landslides. This can be regarded as an upper estimate from single landslides, since a recent estimate indicates lower release [Paull et al., 2007]. Our models do not include this as a potential carbon source.

\subsection{Model Inputs}

[26] Clearly, large uncertainties exist in the amount of carbon stored in Arctic permafrost as methane hydrates, the fraction emitted as $\mathrm{CH}_{4}$ from thawing permafrost and the timing and magnitude of potential emissions from thawing permafrost and gas hydrates. Combining these with our limited knowledge of the rate and degree of long-term global warming it is clear that our estimates of the impact of future emissions of $\mathrm{CH}_{4}$ on atmospheric composition and on climate are also associated with large uncertainties. In order to demonstrate the potential contribution of high-latitude release of $\mathrm{CH}_{4}$ to global warming, several scenarios are considered here. The scenarios discussed in section 5 are based on the potential future emissions of $\mathrm{CH}_{4}$ estimated for the Arctic permafrost region and for $\mathrm{CH}_{4}$ stored in hydrates. The estimates include (1) sustained emissions over a specified time horizon from permafrost thawing necessary to reach a defined level of atmospheric $\mathrm{CH}_{4}$ enhancement and (2) a hypothetical release of $50 \mathrm{Pg}$ of $\mathrm{CH}_{4}$ from the hydrate pool as a pulse over a limited period of time ( 1 year) or as sustained emissions over several decades. Although the high-emission scenarios are unlikely to occur, they are compatible with the current knowledge of the cumulative magnitude of $\mathrm{CH}_{4}$ that might be emitted from permafrost thawing and from $\mathrm{CH}_{4}$ hydrate destabilization.

\section{Atmospheric $\mathrm{CH}_{4}$ Oxidation}

[27] This section provides a brief description of the atmospheric chemistry leading to the formation of greenhouse gases from $\mathrm{CH}_{4}$ emissions.

[28] $\mathrm{CH}_{4}$ oxidation leads to enhanced formation of ozone in the troposphere and lower stratosphere through a sequence of reactions involving $\mathrm{NO}_{\mathrm{x}}$ compounds. The $\mathrm{CH}_{3}$ resulting from reaction (R1) is oxidized and the reaction products are photolyzed in the presence of sunlight:

$$
\begin{aligned}
& \mathrm{CH}_{3}+\mathrm{O}_{2}+\mathrm{M} \rightarrow \mathrm{CH}_{3} \mathrm{O}_{2}+\mathrm{M} \\
& \mathrm{CH}_{3} \mathrm{O}_{2}+\mathrm{NO} \rightarrow \mathrm{CH}_{3} \mathrm{O}+\mathrm{NO}_{2}
\end{aligned}
$$

$$
\begin{gathered}
\mathrm{CH}_{3} \mathrm{O}+\mathrm{O}_{2} \rightarrow \mathrm{CH}_{2} \mathrm{O}+\mathrm{HO}_{2} \\
\mathrm{CH}_{2} \mathrm{O}+\mathrm{h} \nu \rightarrow \mathrm{CO}+\mathrm{H}_{2} \\
\mathrm{CH}_{2} \mathrm{O}+\mathrm{h} \nu \rightarrow \mathrm{CHO}+\mathrm{H} \\
\mathrm{CH}_{2} \mathrm{O}+\mathrm{OH} \rightarrow \mathrm{H}_{2} \mathrm{O}+\mathrm{CHO} \\
\mathrm{CHO}+\mathrm{O}_{2} \rightarrow \mathrm{CO}+\mathrm{HO}_{2} \\
\mathrm{CO}+\mathrm{OH} \rightarrow \mathrm{CO}_{2}+\mathrm{H} \\
\mathrm{H}+\mathrm{O}_{2}+\mathrm{M} \rightarrow \mathrm{HO}_{2}+\mathrm{M} \\
\mathrm{NO}+\mathrm{HO}_{2} \rightarrow \mathrm{NO}_{2}+\mathrm{OH} \\
\mathrm{O}+\mathrm{O}_{2}+\mathrm{M} \rightarrow \mathrm{O}_{3}+\mathrm{M} \\
\mathrm{NO}_{2}+\mathrm{h} \nu \rightarrow \mathrm{NO}+\mathrm{O}(\lambda<400 \mathrm{~nm})
\end{gathered}
$$

[29] $\mathrm{M}$ is an air molecule (usually $\mathrm{N}_{2}$ ), participating in a three-body reaction, and " $\mathrm{h} \nu$ " represents the solar photon flux. Through this cycle ozone is efficiently formed in the presence of $\mathrm{NO}_{\mathrm{x}}, \mathrm{CO}$ and $\mathrm{CH}_{4}$. The end product of the $\mathrm{OH}$ and $\mathrm{HO}_{2}$ formation from $\mathrm{CH}_{4}$ is water vapor. As two $\mathrm{H}_{2} \mathrm{O}$ molecules are formed from each $\mathrm{CH}_{4}$ molecule, water vapor enhancements due to additional $\mathrm{CH}_{4}$ releases can be important in relative terms in the dry stratosphere. Reaction (R9) yields $\mathrm{CO}_{2}$, constituting another important product from $\mathrm{CH}_{4}$ oxidation. The result of the $\mathrm{CH}_{4}$ oxidation chain is thus the formation of the three greenhouse gases $\mathrm{O}_{3}$, $\mathrm{H}_{2} \mathrm{O}$, and $\mathrm{CO}_{2}$, which comes in addition to the enhancement of $\mathrm{CH}_{4}$ concentrations due to direct emissions.

\section{Experimental Setup}

\subsection{Model Description}

[30] We apply the global-scale Oslo CTM2 model (Oslo Chemical Transport Model). The model runs with meteorology from the European Centre for Medium Range Weather Forecasts (ECMWF) and uses the Second-Order Moments Scheme [Prather, 1986] for advective transport. Surface emissions are based on the EDGARv3.2 database [Olivier and Berdowski, 2001] for anthropogenic emissions, and on the work of Müller [1992] for natural emissions. $\mathrm{CH}_{4}$ levels are prescribed in the troposphere with latitudinal distributions based on observations from the ESRL network [Dlugokencky et al., 2010; Masarie et al., 1991]. The model has a resolution, which is $2.8 \times 2.8$ degrees (T42) horizontally and 60 vertical layers in the troposphere and stratosphere, and has extensive tropospheric and stratospheric chemistry which has been validated in model-model and model-measurement inter comparisons of relevance to $\mathrm{CH}_{4}$ perturbations [Gauss et al., 2006; Isaksen et al., 2005; 
Table 1. Changes in $\mathrm{CH}_{4}$ Burden Chosen for the $2.5 \times \mathrm{CH}_{4}, 4 \times \mathrm{CH}_{4}, 7 \times \mathrm{CH}_{4}$, and $13 \times \mathrm{CH}_{4}$ Cases Addressed by Oslo CTM2 Model Runs, Along With the Lifetimes $\tau_{2}$ as Modeled by Oslo CTM2 and the Increase With Respect to the Base Case Lifetime $\tau_{1}{ }^{\mathrm{a}}$

\begin{tabular}{|c|c|c|c|c|c|c|}
\hline Name of Case & $\Delta \mathrm{M} / \mathrm{M}_{1}$ & Lifetime of $\mathrm{CH}_{4}$ (years), $\tau_{2}$ & $\tau_{2} / \tau_{1}(=\beta)$ & $\Delta \mathrm{e}$ in $\mathrm{Pg} \mathrm{CH}_{4} \mathrm{yr}^{-1}$ & $\Delta \mathrm{e} / \mathrm{e}_{1}$ & $\eta$ \\
\hline $2.5 \times \mathrm{CH}_{4}$ & 1.5 & 12.4 & 1.36 & 0.45 & 0.8 & 1.8 \\
\hline $4 \times \mathrm{CH}_{4}$ & 3 & 14.7 & 1.61 & 0.80 & 1.5 & 2.0 \\
\hline $7 \times \mathrm{CH}_{4}$ & 6 & 18.0 & 1.98 & 1.37 & 2.6 & 2.4 \\
\hline $13 \times \mathrm{CH}_{4}$ & 12 & 22.6 & 2.50 & 2.28 & 4.2 & 2.9 \\
\hline $100 \mathrm{Tg}$ & 0.27 & 9.7 & 1.07 & 0.1 & 0.2 & 1.5 \\
\hline $200 \mathrm{Tg}$ & 0.58 & 10.4 & 1.15 & 0.2 & 0.4 & 1.6 \\
\hline Hydrate & $10.78^{\mathrm{b}}$ & $21.2^{\mathrm{b}}$ & $2.34^{\mathrm{b}}$ & 50 (1 year only) & 93 & $2.7^{\mathrm{b}}$ \\
\hline
\end{tabular}

${ }^{a}$ Also shown are the emission enhancements required to bring about the chosen enhancements in atmospheric $\mathrm{CH}_{4} \cdot \mathrm{M}_{1}=4.9 \mathrm{Pg} \mathrm{CH}_{4}, \mathrm{e}_{1}=540 \mathrm{Tg} \mathrm{CH}$ $\mathrm{yr}^{-1}$, and $\tau_{1}=9.1$ years refer to $\mathrm{CH}_{4}$ burden, emission and lifetime in the base case. $\Delta \mathrm{M}$ and $\Delta \mathrm{e}$ denote the absolute increases from the base to the perturbation cases. The enhancement factor $\eta$ (see text) is a measure of the positive feedback in the chemistry of $\mathrm{CH}_{4}$ and is calculated from the changes in $\mathrm{CH}_{4}$ lifetime and burden at the new equilibrium. The three last rows show additional cases, which have not been simulated by the Oslo CTM2 model, but are based on emission estimates assuming thawing of permafrost, and a sudden release of $\mathrm{CH}_{4}$ from marine sediments.

${ }^{\mathrm{b}}$ Numbers apply to peak concentrations reached after 1 year.

Shindell et al., 2006]. The model is further documented by Berglen et al. [2004] and Søvde et al. [2008].

\subsection{Simulations and Definitions}

[31] In the Oslo CTM2 model simulations atmospheric $\mathrm{CH}_{4}$ levels are fixed. The estimates of corresponding emissions are made with a forward explicit box model and described in more detail in section 5. Five simulations are made with 2003 meteorology. A base case simulation with present-day $\mathrm{CH}_{4}$ levels, and 4 perturbation cases with tropospheric $\mathrm{CH}_{4}$ levels multiplied by 2.5 (" $2.5 \times \mathrm{CH}_{4}$ "), four ("4 $\times \mathrm{CH}_{4}$ "), seven ("7 $\times \mathrm{CH}_{4}$ "), and thirteen ("13 $\times \mathrm{CH}_{4}$ "). For chlorine and bromine levels we use values suggested by $W M O$ [2003] for 2100, as we are considering long-term future changes. In each of the simulations the global lifetime of $\mathrm{CH}_{4}$ is calculated from a mass-weighted average of loss through reaction with $\mathrm{OH}$. The base case simulation was spun up for several model years until a stable chemical composition was reached in both the troposphere and the stratosphere. Starting from the resulting chemical fields, both the base case and the perturbation cases were run for an additional 4 years to reach a new equilibrium corresponding to the respective $\mathrm{CH}_{4}$ levels.

[32] In the calculations we have used current atmospheric water vapor content. Since water vapor is expected to increase in a future warmer climate the calculations were repeated for a $40 \%$ increase in tropospheric water vapor (but no other changes). Such perturbations in tropospheric water vapor are expected to be representative for strongly perturbed future climate conditions and key compounds in the interactive climate-chemistry system like $\mathrm{OH}$ and $\mathrm{O}_{3}$ will be affected. We found that the calculated tracer and lifetime perturbations were only slightly affected by this increase (less than $10 \%$ impact).

[33] We define an enhancement factor $\eta$ to quantify the effect of $\mathrm{CH}_{4}$ emissions on its own concentration and lifetime. $\eta$ is given as the ratio of relative change in $\mathrm{CH}_{4}$ burden over relative change in $\mathrm{CH}_{4}$ emissions, i.e., $\eta=\left(\mathrm{M}_{2}-\mathrm{M}_{1}\right) /$ $\mathrm{M}_{1} /\left(\mathrm{e}_{2}-\mathrm{e}_{1}\right) / \mathrm{e}_{1}$, where $\mathrm{M}$ and e represent the global $\mathrm{CH}_{4}$ burden and global $\mathrm{CH}_{4}$ emission at steady state, respectively. Subscript 1 is for the base case, and subscript 2 is for the perturbation cases. The feedback in atmospheric concentration from emissions is positive if $\eta>1$. We define further the ratio of burden $\alpha=\mathrm{M}_{2} / \mathrm{M}_{1}$ and the ratio of $\mathrm{CH}_{4}$ lifetimes as $\beta=\tau_{2} / \tau_{1}$.

\section{Results}

\subsection{Atmospheric Enhancement of $\mathrm{CH}_{4}$}

[34] Estimates of current atmospheric $\mathrm{CH}_{4}$ lifetime are in the range 8 to 10 years [Shindell et al., 2006]. In the Oslo CTM2 model the lifetime of $\mathrm{CH}_{4}$ amounts to 9.1 years in the base case. Table 1 summarizes the main results for the four perturbation cases. For example, in the $4 \times \mathrm{CH}_{4}$ case we choose a fourfold increase in atmospheric $\mathrm{CH}_{4}$, i.e., $\alpha=4$ (or $\Delta \mathrm{M} / \mathrm{M}_{1}=3$ ) in the Oslo CTM2 model calculation and obtain a new $\mathrm{CH}_{4}$ lifetime of $\tau_{2}=14.7$ years, giving a relative increase in lifetime of $\beta=1.61$. The $7 \times \mathrm{CH}_{4}$ case with $\alpha=7$ almost doubles the $\mathrm{CH}_{4}$ lifetime, $\beta=1.98$.

[35] Figure 1 shows $\beta$ as a function of $\mathrm{CH}_{4}$ increase. The circles show the increases of $\mathrm{CH}_{4}$ lifetime as represented by $\beta=\tau_{2} / \tau_{1}$ for the four different cases of enhancement modeled by Oslo CTM2. To obtain intermediate values of $\beta$ we apply cubic interpolation, which is assumed to approximate the relation between $\beta$ and $\alpha\left(=\mathrm{M}_{2} / \mathrm{M}_{1}\right)$ well within the considered range.

\subsection{Calculated Atmospheric Changes in $\mathrm{H}_{2} \mathrm{O}, \mathrm{OH}$, and Ozone}

[36] Figure 2 shows model calculated changes in zonalmean atmospheric water vapor, $\mathrm{OH}$, and ozone for the $4 \times$ $\mathrm{CH}_{4}, 7 \times \mathrm{CH}_{4}$, and $13 \times \mathrm{CH}_{4}$ cases. Related to the negative height dependence of $\mathrm{CH}_{4}$ mixing ratio, stratospheric water vapor increases strongly with height. More $\mathrm{CH}_{4}$ leads to more stratospheric water vapor, and this increase is also significant below $30 \mathrm{~km}$ where stratospheric water vapor is radiatively efficient. $\mathrm{OH}$ decreases strongly in most of the troposphere due to increased $\mathrm{CH}_{4}$ oxidation. The strongest decrease in $\mathrm{OH}$ is found in the lower troposphere with reductions by more than $50 \%$ in the three cases. In the stratosphere, $\mathrm{OH}$ increases as a result of enhanced production from water vapor. The ozone increase is particularly large in the upper tropical troposphere where the ozone radiative forcing is strong [Ramaswamy et al., 2001], while in the lower stratosphere the ozone increase is modest, with regions where ozone even decreases slightly when $\mathrm{CH}_{4}$ is perturbed. 


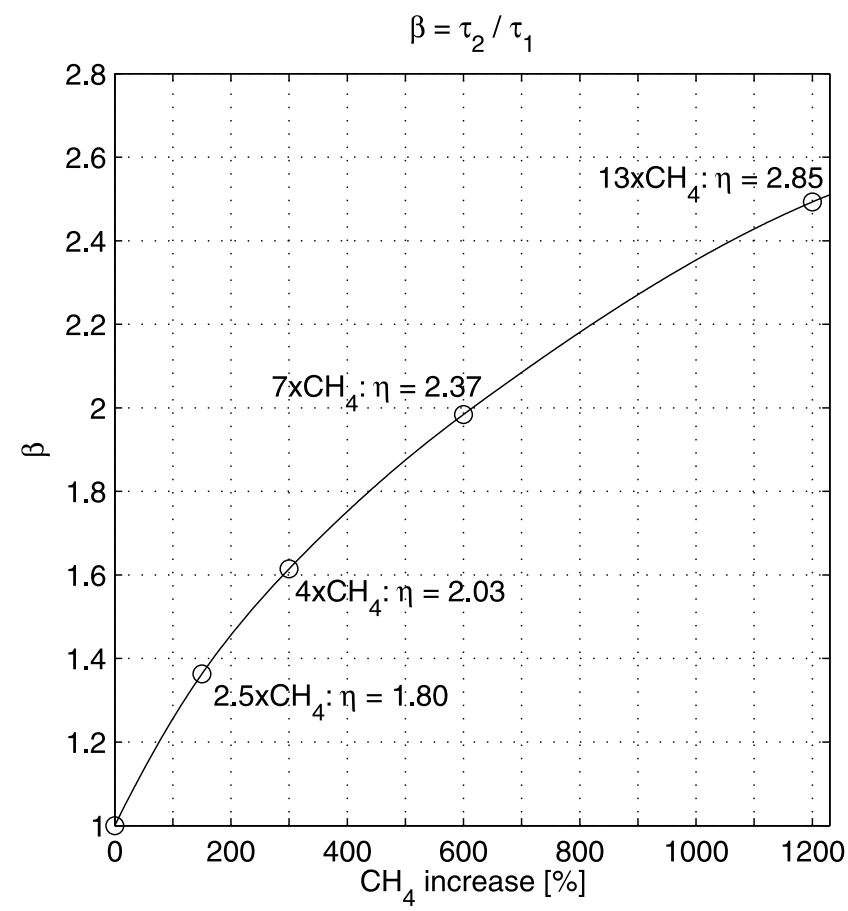

Figure 1. The increase in $\mathrm{CH}_{4}$ lifetime as a function of the increase in $\mathrm{CH}_{4}$ burden.
In the upper stratosphere ozone is reduced due to the more efficient removal by $\mathrm{HO}_{\mathrm{x}}$ (odd hydrogen) reactions.

\subsection{Relating the Chosen $\mathrm{CH}_{4}$ Enhancements to Emissions and Available Storage}

[37] A forward explicit box model is applied to calculate the evolution of $\mathrm{CH}_{4}$ as function of time assuming different (sustained) $\mathrm{CH}_{4}$ emission rates. The calculation starts at present $\mathrm{CH}_{4}$ levels, and at each time step $(0.01$ years) it uses the $\mathrm{CH}_{4}$ lifetime that corresponds to the $\mathrm{CH}_{4}$ concentration calculated by the box model for the current time step. The relation between $\mathrm{CH}_{4}$ lifetime and concentration calculated in the Oslo CTM2 simulations (Figure 1) is taken as input to the box model. The resulting evolution of $\mathrm{CH}_{4}$ is shown in Figure $3.96 \%, 92 \%$ and $87 \%$ of the chosen increases are reached after 50 years in the $2.5 \times \mathrm{CH}_{4}, 4 \times \mathrm{CH}_{4}$ and $7 \times$ $\mathrm{CH}_{4}$ cases, respectively, reflecting the increase in lifetime with increasing emission.

[38] Table 1 also lists the additional $\mathrm{CH}_{4}$ emissions $(\Delta \mathrm{e})$ needed to reach the adopted equilibrium enhancement values in the different perturbation experiments. These additional emissions are switched on in the forward explicit box model from the beginning. The base case level is consistent with an emission of $540 \mathrm{Tg} \mathrm{CH}_{4} \mathrm{yr}^{-1}$. Total equilibrium emissions can thus be obtained by adding $540 \mathrm{Tg} \mathrm{CH}_{4} \mathrm{yr}^{-1}$ to the values given in Table 1. However, an important question in relation to the equilibrium value is the timescale for the additional emission.

[39] Our highest estimate for thermokarst lakes is a 100 to $200 \mathrm{Tg} \mathrm{CH}_{4} \mathrm{yr}^{-1}$ emission, which can be sustained for a
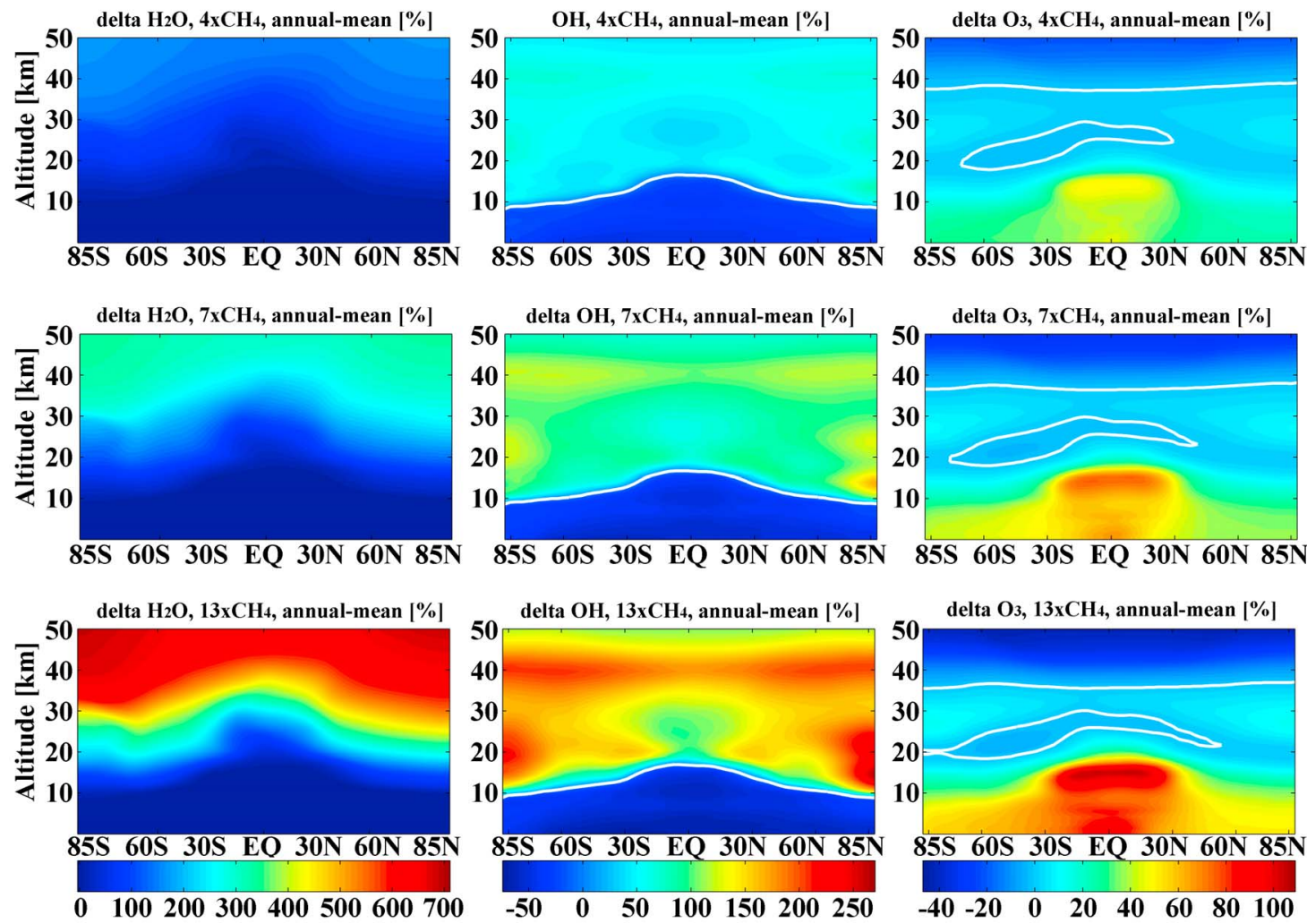

Figure 2. Annual and zonal mean relative change in stratospheric water vapor, the hydroxyl radical, and ozone for 4,7 , and 13 times current $\mathrm{CH}_{4}$ levels. White contour lines indicate zero change. 


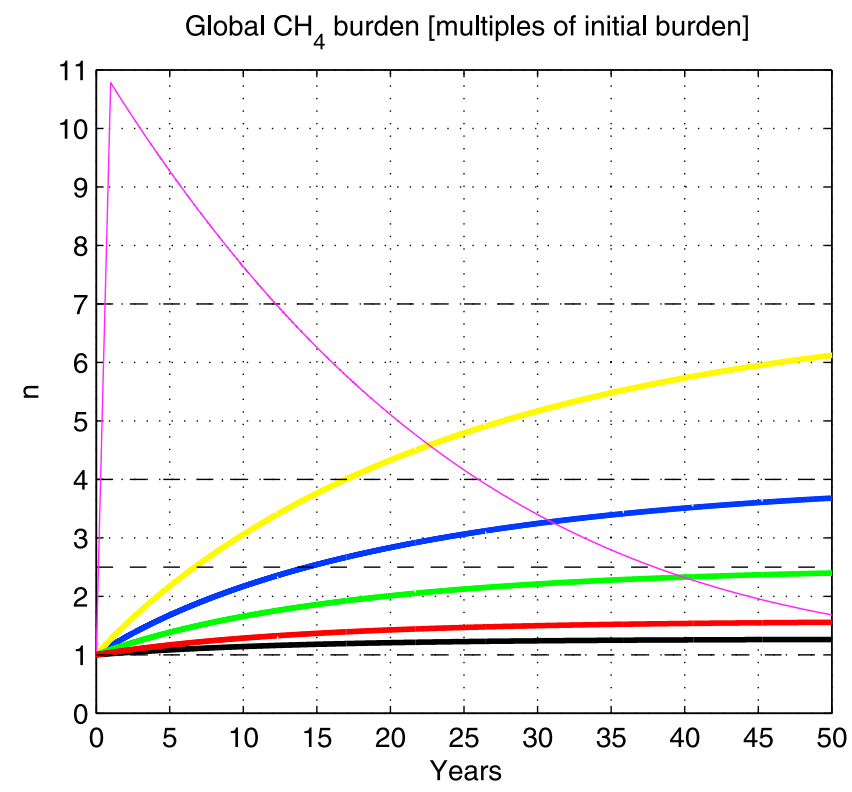

Figure 3. Global $\mathrm{CH}_{4}$ burden as function of time for scenarios $2.5 \times \mathrm{CH}_{4}$ (green), $4 \times \mathrm{CH}_{4}$ (blue), and $7 \times \mathrm{CH}_{4}$ (yellow). Additional scenarios are indicated, for which Oslo CTM2 simulations where not performed, but the lifetime dependence of $\mathrm{CH}_{4}$ on its own concentration is taken into account: $100 \mathrm{Tg}\left(\mathrm{CH}_{4}\right) \mathrm{yr}^{-1}$ sustained (black), $200 \mathrm{Tg}$ $\left(\mathrm{CH}_{4}\right) \mathrm{yr}^{-1}$ sustained (red), and a 1 year $50 \mathrm{Pg}\left(\mathrm{CH}_{4}\right) \mathrm{yr}^{-1}$ emission scenario ("hydrate" scenario, purple). Horizontal gray lines denote current global burden (1) and the three enhanced levels $2.5,4$, and 7 .

time period of up to 500 years. Such enhanced emissions would increase the $\mathrm{CH}_{4}$ lifetime by about 7 to $15 \%$, and the $\mathrm{CH}_{4}$ burden by factors of 1.3 to 1.6 (Table 1 ).

[40] To illustrate the atmospheric impact on $\mathrm{CH}_{4}$ of large pulse type releases, we assume a hypothetical case of $50 \mathrm{Pg}$ $\mathrm{CH}_{4}$ emission, corresponding to $\mathrm{CH}_{4}$ hydrate releases from the Siberian Arctic shelf (as defined in section 2). The atmospheric impact for a pulse emission (over 1 year) and for sustained emissions over several decades, are considered. Our calculations (Figure 3) show that a 1 year pulse emission of $50 \mathrm{Pg} \mathrm{CH}_{4}$ would lead to abundances peaking at about 11 times its current level. Table 1 gives the yearly emissions needed to give equilibrium abundances in the atmosphere 2.5 times, 4 times and 7 times current abundances. A total of $50 \mathrm{Pg} \mathrm{CH} \mathrm{CH}_{4}$ can sustain the additional emissions in the three cases for $111,62.5$, and 36.5 years, respectively, giving enhancements that are approaching the equilibrium values.

[41] For the sustained $100 \mathrm{Tg} \mathrm{CH}_{4} \mathrm{yr}^{-1}, 200 \mathrm{Tg} \mathrm{CH}_{4} \mathrm{yr}^{-1}$ and the 1 year $50 \mathrm{Pg} \mathrm{CH}_{4}$ emission cases, the $\mathrm{CH}_{4}$ lifetime dependence derived from the four explicit Oslo CTM2 simulations (shown in Figure 1) is taken into account in the calculation of $\mathrm{CH}_{4}$ evolution.

\subsection{Atmospheric Enhancement of $\mathrm{CO}_{2}$}

[42] $\mathrm{CH}_{4}$ is oxidized to $\mathrm{CO}_{2}$ in the atmosphere, and $\mathrm{CO}_{2}$ decays according to different loss processes. Our calculation of the evolution of $\mathrm{CO}_{2}$ (shown in Figure 4) from oxidation of the $\mathrm{CH}_{4}$ released from thawing permafrost or hydrate storage is based on the formula of IPCC-AR4 [Forster et al., 2007], according to which the decay of a pulse of $\mathrm{CO}_{2}$ with time $\mathrm{t}$ is given by

$$
a_{0}+\sum_{i=1}^{3} a_{i} \cdot \exp \left(-t / \tau_{i}\right)
$$

Where $\mathrm{a}_{0}=0.217, \mathrm{a}_{1}=0.259, \mathrm{a}_{2}=0.338, \mathrm{a}_{3}=0.186, \tau_{1}=$ 172.9 years, $\tau_{2}=18.51$ years, and $\tau_{3}=1.186$ years. The pulses at each time step are set equal to the amount that is oxidized from the additional atmospheric $\mathrm{CH}_{4}$ from permafrost emissions. After 50 years, the $\mathrm{CO}_{2}$ values are 4.4, 7.3, and $11.3 \mathrm{ppm}(\mathrm{ppm})$ for the $2.5 \times \mathrm{CH}_{4}, 4 \times \mathrm{CH}_{4}$, and $7 \times$ $\mathrm{CH}_{4}$ cases, respectively. For comparison with Figure 3, Figure 4 also includes the $\mathrm{CH}_{4}$ hydrate case for which the $\mathrm{CO}_{2}$ enhancement peaks at around $10 \mathrm{ppm}$ after 40 to 50 years. It has to be noted that the $\mathrm{CO}_{2}$ shown in Figure 4 does not include directly emitted $\mathrm{CO}_{2}$ from permafrost thaw. The inclusion of $\mathrm{CO}_{2}$ in these calculations is consistent with the inclusion of $\mathrm{CH}_{4}$ oxidation to $\mathrm{CO}_{2}$ in the GWP for $\mathrm{CH}_{4}[$ Boucher et al., 2009].

\subsection{Radiative Forcing}

[43] Detailed off-line atmospheric radiative transfer schemes are used in the calculations of radiative forcing (RF), from changes in ozone and stratospheric water vapor $\left(\mathrm{sH}_{2} \mathrm{O}\right)$ [Myhre et al., 2000; Myhre et al., 2007]. For $\mathrm{CO}_{2}$ and $\mathrm{CH}_{4}$, expressions given by Ramaswamy et al. [2001] are used. The radiative forcing is not related to a particular year but to the time when the $\mathrm{CH}_{4}$ increase is reached. The $13 \times$

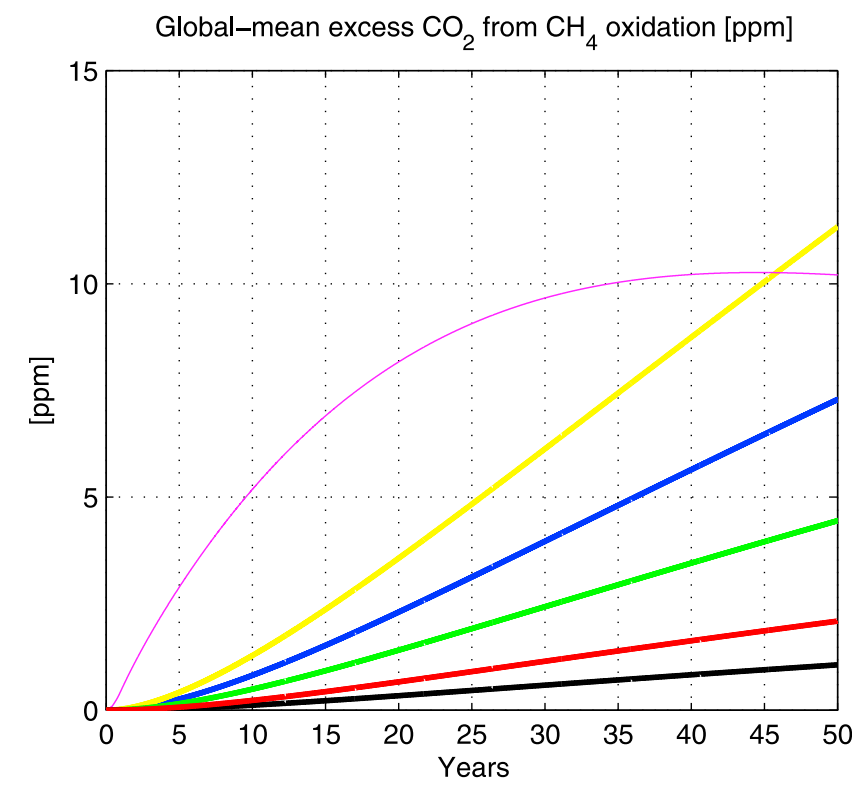

Figure 4. Global-mean mixing ratio of excess $\mathrm{CO}_{2}$ from additional $\mathrm{CH}_{4}$ oxidation for scenarios $2.5 \times \mathrm{CH}_{4}$ (green), $4 \times \mathrm{CH}_{4}$ (blue), and $7 \times \mathrm{CH}_{4}$ (yellow). Additional scenarios are indicated, for which Oslo CTM2 simulations where not performed, but the lifetime dependence of $\mathrm{CH}_{4}$ on its own concentration is taken into account: $100 \mathrm{Tg} \mathrm{CH}_{4} \mathrm{yr}^{-1}$ sustained (black), $200 \mathrm{Tg} \mathrm{CH}_{4} \mathrm{yr}^{-1}$ sustained (red), and $50 \mathrm{Pg} \mathrm{CH}_{4} \mathrm{yr}^{-1}$ switched off after 1 year ("hydrate" scenario, purple). 


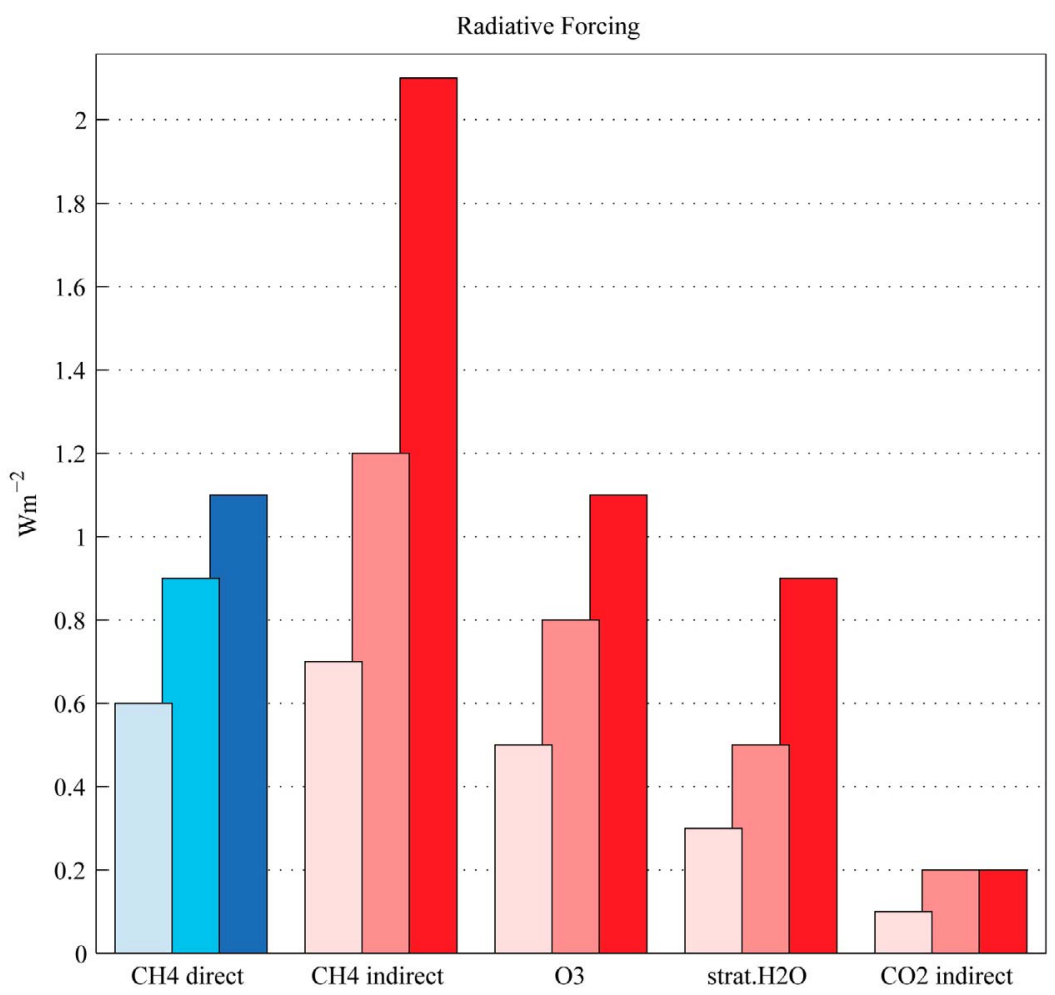

Figure 5. Radiative forcing resulting from $\mathrm{CH}_{4}$ increases. Blue bars denote contributions from direct emissions, and red bars are contributions from $\mathrm{CH}_{4}$ initiated changes in atmospheric composition. " $\mathrm{CH}_{4}$ indirect" represents the $\mathrm{CH}_{4}$ enhancement that is due to the increase in its lifetime. " $\mathrm{CO}_{2}$ indirect" relates to the $\mathrm{CO}_{2}$ enhancement due to oxidation of the additional $\mathrm{CH}_{4}$. The lightest colors refer to the $4 \times$ $\mathrm{CH}_{4}$, medium light colors to the $7 \times \mathrm{CH}_{4}$ and dark colors to the $13 \times \mathrm{CH}_{4}$ case. The radiative forcing is not related to a particular year but to the time when the $\mathrm{CH}_{4}$ increase is reached. The $13 \times \mathrm{CH}_{4}$ case refers to a shorter time horizon (30 years) while the other cases are based on a 50 year time horizon.

$\mathrm{CH}_{4}$ case refers to a shorter time horizon (30 years) while the other cases are based on a 50 year time horizon.

[44] Results are shown in Figure 5 for the $4 \times \mathrm{CH}_{4}, 7 \times$ $\mathrm{CH}_{4}$ and $13 \times \mathrm{CH}_{4}$ cases. Radiative forcings due to $\mathrm{CH}_{4}$ are listed in Table 2. In the $4 \times \mathrm{CH}_{4}$ case the $\mathrm{RF}$ caused by direct emissions of $\mathrm{CH}_{4}$ and the $\mathrm{RF}$ due to the lifetime increase are comparable and add up to $1.3 \mathrm{Wm}^{-2}$. The RF of $0.5 \mathrm{Wm}^{-2}$ from ozone, calculated for the same case, is probably stronger than the forcing since preindustrial time [Gauss et al., 2006]. For $\mathrm{sH}_{2} \mathrm{O}$ we calculate nearly quadrupling $\left(0.3 \mathrm{Wm}^{-2}\right)$ of the current $\mathrm{sH}_{2} \mathrm{O}$ forcing $(0.08$ $\mathrm{Wm}^{-2}$ ) [Myhre et al., 2007]. In the $7 \times \mathrm{CH}_{4}$ and $13 \times \mathrm{CH}_{4}$ cases the indirect $\mathrm{CH}_{4} \mathrm{RF}$ clearly dominates the direct one, due to more pronounced $\mathrm{OH}$ changes. The total RF is 2.2, 3.6 , and $5.4 \mathrm{Wm}^{-2}$ for the $4 \times \mathrm{CH}_{4}, 7 \times \mathrm{CH}_{4}$ and $13 \times \mathrm{CH}_{4}$ cases, respectively.

[45] The importance of $\mathrm{CH}_{4}$ emissions through atmospheric chemistry perturbation is illustrated by a 3.5- to fivefold increase in the total RF compared to the contribution from direct emissions, increasing in importance with the increase in $\mathrm{CH}_{4}$ emission. The impact of chemical perturbations by $\mathrm{CH}_{4}$ emission increases is substantially higher than what is included in the GWP value for $\mathrm{CH}_{4}$ used in IPCC [Forster et al., 2007], where a twofold increase in RF was adopted to account for indirect effects at current conditions. The $\mathrm{CH}_{4}$ lifetime feedback represents the most important contribution among the additional radiative for- cings due to changes in atmospheric composition, followed by ozone (in particular tropospheric ozone) and $\mathrm{sH}_{2} \mathrm{O}$.

[46] According to our simulations, sustained $\mathrm{CH}_{4}$ emissions of $100 \mathrm{Tg} \mathrm{yr}^{-1}$ to $200 \mathrm{Tg} \mathrm{yr}^{-1}$ due to permafrost thawing will correspond to a RF of 0.3 to $0.6 \mathrm{Wm}^{-2}$ in a new equilibrium (reached after a few decades). Although the amount of $\mathrm{CH}_{4}$ released to the atmosphere is large, the short lifetime ( 8 to 10 years) compared to the time horizon for

Table 2. Radiative Forcing Due to Directly Emitted $\mathrm{CH}_{4}\left(\mathrm{CH}_{4}\right.$ Direct Forcing), the Lifetime Change of $\mathrm{CH}_{4}\left(\mathrm{CH}_{4}\right.$ Indirect Forcing), and the Chemical Enhancements Due to the Feedbacks in the $4 \times \mathrm{CH}_{4}, 7 \times \mathrm{CH}_{4}$, and $13 \times \mathrm{CH}_{4}$ Cases $^{\mathrm{a}}$

\begin{tabular}{lccc}
\hline & $\begin{array}{c}\mathrm{CH}_{4} \\
\text { Direct } \\
\text { Forcing }\end{array}$ & $\begin{array}{c}\mathrm{CH}_{4} \\
\text { Indirect } \\
\text { Forcing }\end{array}$ & $\begin{array}{c}\text { Indirect } \\
\text { Forcing FromO } \\
\text { strat. } \mathrm{H}_{2} \mathrm{O} \\
\text { and } \mathrm{CO}_{2}\end{array}$ \\
\hline $4 \times \mathrm{CH}_{4}$ & $0.6 \mathrm{Wm}^{-2}$ & $0.7 \mathrm{Wm}^{-2}$ & $0.9 \mathrm{Wm}^{-2}$ \\
$7 \times \mathrm{CH}_{4}$ & $0.9 \mathrm{Wm}^{-2}$ & $1.2 \mathrm{Wm}^{-2}$ & $1.5 \mathrm{Wm}^{-2}$ \\
$13 \times \mathrm{CH}_{4}$ & $1.1 \mathrm{Wm}^{-2}$ & $2.1 \mathrm{Wm}^{-2}$ & $2.2 \mathrm{Wm}^{-2}$ \\
$100 \mathrm{Tg}$ & $0.1 \mathrm{Wm}^{-2}$ & $0.1 \mathrm{Wm}^{-2}$ & $0.1 \mathrm{Wm}^{-2}$ \\
$200 \mathrm{Tg}$ & $0.2 \mathrm{Wm}^{-2}$ & $0.2 \mathrm{Wm}^{-2}$ & $0.2 \mathrm{Wm}^{-2}$ \\
\hline
\end{tabular}

"For the "100 Tg" and "200 Tg" cases (in the table listed in italics) no Oslo CTM2 calculations have been made. Thus the split into direct and indirect components of radiative forcing is based on extrapolated values for $\beta$. Contributions to indirect radiative forcing from perturbations of $\mathrm{O}_{3}$, stratospheric $\mathrm{H}_{2} \mathrm{O}$ and $\mathrm{CO}_{2}$ are not included in the table. 
emission (up to 500 years) means that equilibrium in atmospheric concentration is reached at an early stage in the time period. As an illustration of the potential of permafrost $\mathrm{CH}_{4}$ releases, the increase of the $\mathrm{CH}_{4}$ concentration by a factor 2.5 compared to current $\mathrm{CH}_{4}$ concentrations would correspond to an extra emission of $450 \mathrm{Tg} \mathrm{CH}_{4} \mathrm{yr}^{-1}$ from permafrost thawing and give a radiative forcing of about $1.5 \mathrm{Wm}^{-2}$. However, the emission would be over a shorter time horizon than in the $100 \mathrm{Tg} \mathrm{CH}_{4} \mathrm{yr}^{-1}$ to $200 \mathrm{Tg} \mathrm{CH}_{4} \mathrm{yr}^{-1}$ emission cases.

[47] A release of $50 \mathrm{Pg}\left(\mathrm{CH}_{4}\right)$ from gas hydrates over a 30 year time period could give a RF in excess of $4 \mathrm{Wm}^{-2}$. The larger calculated RF, results from the fact that this case represents a more rapid emission than our $7 \times \mathrm{CH}_{4}$ case.

[48] The release of up to $5 \mathrm{Pg} \mathrm{C}$ estimated for single submarine landslides (see discussion in section 2) can enhance atmospheric $\mathrm{CH}_{4}$ by nearly $2.5 \mathrm{ppm}$, and give a RF slightly larger than $1 \mathrm{Wm}^{-2}$. This is substantially higher than the $0.2 \mathrm{Wm}^{-2}$ (only the direct RF was taken into account) from a similar $\mathrm{CH}_{4}$ release discussed by Archer [2007]. It has to be noted, however, that more recent estimates of the emission from the Storegga Landslide are lower than $5 \mathrm{Pg} \mathrm{C}$ [e.g., Paull et al., 2007], and that there is no evidence that the $\mathrm{CH}_{4}$ released escaped to the atmosphere after the event.

\section{Discussion and Conclusion}

[49] Relating the magnitude and timing of $\mathrm{CH}_{4}$ release in a warming Arctic to the adopted scenarios applied in the model studies is challenging due to uncertainties associated with the rate of permafrost warming and thawing, the size and distribution of the large organic $\mathrm{C}$ pool [Tarnocai et al., 2009] and its fate in microbial decomposition under aerobic versus anaerobic conditions [Schuur et al., 2008; Walter et al., 2007], and the size and stability of the hydrate reservoir. However, given the magnitude and vulnerability of the permafrost organic carbon pool and the large permafrostassociated $\mathrm{CH}_{4}$ hydrate reservoir, quantification of the feedbacks associated with the release of $\mathrm{CH}_{4}$ from these systems is important for climate modeling.

[50] There is a potential for the release of large amounts of carbon stored in the Arctic to the atmosphere as $\mathrm{CH}_{4}$ following the thawing of permafrost and warming of oceans [Buffett and Archer, 2004; Schuur et al., 2008; Walter et al., 2007, 2006]. Considering the positive feedback (increase in lifetime) and the non linearity in atmospheric chemistry through amplification of atmospheric $\mathrm{CH}_{4}$ (represented by the enhancement factor $\eta$ ), we have applied a wide range of $\mathrm{CH}_{4}$ emission scenarios to explore the impact of such interactions. The impact on methane lifetime does not only apply to the additionally emitted $\mathrm{CH}_{4}$ but also to background levels of $\mathrm{CH}_{4}$.

[51] Although the high- $\mathrm{CH}_{4}$ scenarios applied in this study are unlikely, they demonstrate the strong $\mathrm{CH}_{4}$ feedbacks in the climate system, with large amplification of atmospheric composition changes and RF compared to the direct $\mathrm{RF}$ of $\mathrm{CH}_{4}$ emissions.

[52] The Oslo CTM2 has been thoroughly tested with respect to $\mathrm{OH}$ and $\mathrm{CH}_{4}$ lifetime through model comparisons and through perturbation studies [Hoor et al., 2009; Shindell et al., 2006]. These studies show that there are noticeable differences in model estimates. Another model uncertainty in the Oslo CTM2 calculations may arise from the use of today's meteorology, uncertainties in emissions of other gases than $\mathrm{CH}_{4}$ (e.g., emissions of $\mathrm{NO}_{\mathrm{x}}$ and $\mathrm{CO}$ ), and the formulation of dry deposition $\left(\mathrm{O}_{3}\right)$ and wet deposition $\left(\mathrm{NO}_{\mathrm{x}}\right)$ [Isaksen et al., 2005; Solberg et al., 2008]. Yet, the uncertainties in the atmospheric chemistry calculations are likely to be small compared to the uncertainties in the amount and time horizon for $\mathrm{CH}_{4}$ emission from thawing permafrost or degassing hydrates.

[53] Since current atmospheric $\mathrm{CH}_{4}$ lifetime ranges between 8 and 10 years, the RF of $\mathrm{CH}_{4}$ emissions from permafrost thawing and $\mathrm{CH}_{4}$ hydrate degassing depends critically on the rate of emissions. Additional studies linking $\mathrm{CH}_{4}$ emissions to the possibilities for large future warming in the Arctic are needed.

[54] Although $\mathrm{CH}_{4}$ emissions from permafrost thawing and hydrate degassing are likely to have a very different spatiotemporal distribution than anthropogenic emissions, the impact on climate will be global in the same way as the impact from $\mathrm{CH}_{4}$ emitted in other regions, when we take into account the multiyear lifetime of $\mathrm{CH}_{4}$.

[55] Fossil fuel $\mathrm{CO}_{2}$ emissions have increased substantially over the last decade and is now $40 \%$ higher than in 1990 [Le Quéré et al., 2009; Myhre et al., 2009]. The continued increase in greenhouse gas emissions toward the end of this century has the potential to produce significant warming at high northern latitudes well beyond what has been observed during the last decades [Hansen et al., 2007; $I P C C, 2007]$. There is a possibility that the Arctic temperature increases could be followed by extensive permafrost thawing, with enhanced $\mathrm{CH}_{4}$ emission from thermokarst lakes [Walter et al., 2006], with later release of $\mathrm{CH}_{4}$ from gas hydrates that would eventually be affected by warming temperatures. Considering the large, nonlinear atmospheric chemistry feedbacks discussed here, future $\mathrm{CH}_{4}$ emissions from permafrost deposits could be a larger concern for climate warming than previously thought.

\section{References}

Archer, D. (2007), Methane hydrate stability and anthropogenic climate change, Biogeosciences, 4(4), 521-544, doi:10.5194/bg-4-521-2007.

Berglen, T. F., T. K. Berntsen, I. S. A. Isaksen, and J. K. Sundet (2004), A global model of the coupled sulfur/oxidant chemistry in the troposphere: The sulfur cycle, J. Geophys. Res., 109, D19310, doi:10.1029/ 2003JD003948.

Boswell, R., and T. S. Collett (2011), Current perspectives on gas hydrate resources, Energy Environ. Sci., 4, 1206-1215, doi:10.1039/C0EE00203H.

Boucher, O., P. Friedlingstein, B. Collins, and K. P. Shine (2009), The indirect global warming potential and global temperature change potential due to methane oxidation, Environ. Res. Lett., 4, 044007, doi:10.1088/ 1748-9326/4/4/044007.

Bousquet, P., et al. (2006), Contribution of anthropogenic and natural sources to atmospheric methane variability, Nature, 443(7110), 439-443, doi:10.1038/nature05132.

Buffett, B., and D. Archer (2004), Global inventory of methane clathrate: Sensitivity to changes in the deep ocean, Earth Planet. Sci. Lett., 227(3-4), 185-199, doi:10.1016/j.epsl.2004.09.005.

Camill, P. (2005), Permafrost thaw accelerates in boreal peatlands during late-20th century climate warming, Clim. Change, 68(1-2), 135-152, doi:10.1007/s10584-005-4785-y.

Christensen, T. R., T. Johansson, H. J. Åkerman, M. Mastepanov, N. Malmer, T. Friborg, P. Crill, and B. H. Svensson (2004), Thawing sub-Arctic permafrost: Effects on vegetation and methane emissions, Geophys. Res. Lett., 31, L04501, doi:10.1029/2003GL018680.

Dallimore, S. R., and T. S. Collett (1995), Intrapermafrost gas hydrates from a deep core hole in the Mackenzie Delta, Northwest Territories, Canada, Geology, 23, 527-530, doi:10.1130/0091-7613(1995) $023<0527$ :IGHFAD $>2.3$.CO;2. 
Denman, K. L., et al. (2007), Couplings between changes in the climate system and biogeochemistry, in Climate Change 2007: The Physical Science Basis. Contribution of Working Group I to the Fourth Assessment Report of the Intergovernmental Panel on Climate Change, edited by S. Solomon et al., Cambridge Univ. Press, Cambridge, U. K.

Dickens, G. R., J. R. O’Neil, D. C. Rea, and R. M. Owen (1995), Dissociation of oceanic methane hydrate as a cause of the carbon isotope excursion at the end of the Paleocene, Paleoceanography, 10, 965-971, doi:10.1029/ 95PA02087.

Dickens, G. R., M. M. Castillo, and J. C. G. Walker (1997), A blast of gas in the latest Paleocene, Geology, 25, 259-262, doi:10.1130/0091-7613 (1997)025<0259:ABOGIT>2.3.CO;2

Dlugokencky, E. J., S. Houweling, L. Bruhwiler, K. A. Masarie, P. M. Lang, J. B. Miller, and P. P. Tans (2003), Atmospheric methane levels off: Temporary pause or a new steady-state?, Geophys. Res. Lett., 30(19), 1992, doi:10.1029/2003GL018126.

Dlugokencky, E. J., P. M. Lang, and K. A. Masarie (2010), Atmospheric methane dry air mole fractions from the NOAA ESRL Carbon Cycle Cooperative Global Air Sampling Network, 1983-2009, Version: 2010-08-12, ftp://ftp.cmdl.noaa.gov/ccg/ch4/flask/event/, ESRL, NOAA, Boulder, Colo.

Forster, P., et al. (2007), Changes in atmospheric constituents and in radiative forcing, in Climate Change 2007: The Physical Science Basis. Contribution of Working Group I to the Fourth Assessment Report of the Intergovernmental Panel on Climate Change, edited by S. Solomon et al., pp. 129-134, Cambridge Univ. Press, U. K.

Gauss, M., et al. (2006), Radiative forcing since preindustrial times due to ozone change in the troposphere and the lower stratosphere, Atmos. Chem. Phys., 6, 575-599, doi:10.5194/acp-6-575-2006.

Hansen, J., et al. (2007), Dangerous human-made interference with climate: A GISS modelE study, Atmos. Chem. Phys., 7(9), 2287-2312 doi:10.5194/acp-7-2287-2007.

Hoor, P., et al. (2009), The impact of traffic emissions on atmospheric ozone and OH: Results from QUANTIFY, Atmos. Chem. Phys., 9(9), 3113-3136, doi:10.5194/acp-9-3113-2009.

IPCC (2007), The Physical Science Basis. Contribution of Working Group I to the Fourth Assessment Report of the Intergovernmental Panel on Climate Change, edited by S. Solomon et al., Cambridge Univ. Press, Cambridge, U. K.

Isaksen, I. S. A. (1988), Is the Oxidizing Capacity of the Atmosphere Changing? Report of the Dahlem Workshop of the Changing Atmosphere, Berlin, Nov. 1-6, 1987, edited by F. S. Rowland and I. S. A. Isaksen, pp. 141-157, John Wiley, Chichester, U. K.

Isaksen, I. S. A., and Ø. Hov (1987), Calculation of trends in the tropospheric concentration of $\mathrm{O}_{3}, \mathrm{OH}, \mathrm{CO}, \mathrm{CH}_{4}$ and $\mathrm{NO}_{\mathrm{x}}$, Tellus, Ser. B, 39, 271-285, doi:10.1111/j.1600-0889.1987.tb00099.x.

Isaksen, I. S. A., C. Zerefos, K. Kourtidis, C. Meleti, S. B. Dalsoren, J. K. Sundet, A. Grini, P. Zanis, and D. Balis (2005), Tropospheric ozone changes at unpolluted and semipolluted regions induced by stratospheric ozone changes, J. Geophys. Res., 110, D02302, doi:10.1029/ 2004JD004618.

Isaksen, K., J. L. Sollid, P. Holmlund, and C. Harris (2007), Recent warming of mountain permafrost in Svalbard and Scandinavia, J. Geophys. Res., 112, F02S04, doi:10.1029/2006JF000522.

Krey, V., et al. (2009), Gas hydrates: Entrance to a methane age or climate threat?, Environ. Res. Lett., 4(3), doi:10.1088/1748-9326/4/3/034007.

Lamarque, J. F., J. T. Kiehl, C. A. Shields, B. A. Boville, and D. E. Kinnison (2006), Modeling the response to changes in tropospheric methane concentration: Application to the Permian-Triassic boundary, Paleoceanography, 21, PA3006, doi:10.1029/2006PA001276.

Le Quéré, C., et al. (2009), Trends in the sources and sinks of carbon dioxide, Nat. Geosci., 2(12), 831-836, doi:10.1038/ngeo689.

Masarie, K. A., et al. (1991), A rule-based expert system for evaluating the quality of long-term, in situ, gas chromatographic measurements of atmospheric methane, NOAA Tech. Memo. ERL CMDL-3, NOAA Environ. Res. Lab., Boulder, Colo.

Müller, J. (1992), Geographical distribution and seasonal variation of surface emissions and deposition velocities of atmospheric trace gases, J. Geophys. Res., 97(D4), 3787-3804.

Myhre, G., S. Karlsdottir, I. S. A. Isaksen, and F. Stordal (2000), Radiative forcing due to changes in tropospheric ozone in the period 1980 to 1996 J. Geophys. Res., 105(D23), 28,935-28,942, doi:10.1029/2000JD900187.

Myhre, G., J. S. Nilsen, L. Gulstad, K. P. Shine, B. Rognerud, and I. S. A. Isaksen (2007), Radiative forcing due to stratospheric water vapour from $\mathrm{CH}_{4}$ oxidation, Geophys. Res. Lett., 34, L01807, doi:10.1029/ 2006GL027472.

Myhre, G., K. Alterskjaer, and D. Lowe (2009), A fast method for updating global fossil fuel carbon dioxide emissions, Environ. Res. Lett., 4(3), doi:10.1088/1748-9326/4/3/034012.
Olivier, J. G. J., and J. J. M. Berdowski (2001), Global emissions sources and sinks, in The Climate System, edited by J. J. M. Berdowski, R. Guicherit, and B. J. Heij, pp. 33-78, A. A. Balkema Publ., Lisse, Netherlands.

Osterkamp, T. E. (2005), The recent warming of permafrost in Alaska, Global Planet. Change, 49(3-4), 187-202, doi:10.1016/j.gloplacha. 2005.09.001.

Osterkamp, T. E., and J. C. Jorgenson (2006), Warming of permafrost in the Arctic National Wildlife Refuge, Alaska, Permafrost Periglacial Proc., 17(1), 65-69, doi:10.1002/ppp.538.

Paull, C. K., W. Ussler, and W. S. Holbrook (2007), Assessing methane release from the colossal Storegga submarine landslide, Geophys. Res. Lett., 34, L04601, doi:10.1029/2006GL028331.

Plug, L. J., and J. J. West (2009), Thaw lake expansion in a two-dimensional coupled model of heat transfer, thaw subsidence, and mass movement, J. Geophys. Res., 114, F01002, doi:10.1029/2006JF000740.

Prather, M., et al. (2001), Atmospheric chemistry and greenhouse gases, in Climate Change 2001: The Scientific Basis, Contribution of Working Group I to the Third Assessment Report of the Intergovernmental Pane on Climate Change, edited by J. T. Houghton et al., pp. 239-287, Cambridge Univ. Press, Cambridge, U. K.

Prather, M. J. (1986), Numerical advection by conservation of 2nd-order moments, J. Geophys. Res., 91(D6), 6671-6681, doi:10.1029/ JD091iD06p06671.

Rachold, V., D. Y. Bolshiyanov, M. N. Grigoriev, H.-W. Hubberten, R. Junker, V. V. Kunitsky, F. Merker, P. Overduin, and W. Schneider (2007), Nearshore Arctic subsea permafrost in transition, Eos Trans $A G U, 88(13)$, doi:10.1029/2007EO130001.

Ramaswamy, V., O. Boucher, J. Haigh, D. Hauglustaine, J. Haywood, G. Myhre, T. Nakajima, G. Y. Shi, and S. Solomon (2001), Radiative forcing of climate change, in Climate Change 2001: The Scientific Basis, Contribution of Working Group I to the Third Assessment Report of the Intergovernmental Panel on Climate Change, edited by J. T. Houghton et al., pp. 349-416, Cambridge Univ. Press, Cambridge, U. K.

Renssen, H., C. J. Beets, T. Fichefet, H. Goosse, and D. Kroon (2004), Modeling the climate response to a massive methane release from gas hydrates, Paleoceanography, 19, PA2010, doi:10.1029/2003PA000968. Rigby, M., et al. (2008), Renewed growth of atmospheric methane, Geophys. Res. Lett., 35, L22805, doi:10.1029/2008GL036037.

Schmidt, G. A., and D. T. Shindell (2003), Atmospheric composition, radiative forcing, and climate change as a consequence of a massive methane release from gas hydrates, Paleoceanography, 18(1), 1004, doi:10.1029/ 2002PA000757.

Schuur, E. A. G., et al. (2008), Vulnerability of permafrost carbon to climate change: Implications for the global carbon cycle, BioScience, 58(8), 701-714, doi:10.1641/B580807.

Shakhova, N., I. Semiletov, and G. Panteleev. (2005) The distribution of methane on the East Siberian Arctic shelves: Implications for the marine methane cycle, Geophys. Res. Lett., 32, L09601, doi:10.1029/ 2005GL02275

Shakhova, N., I. Semiletov, A. Salyuk, and D. Kosmach (2008), Anomalies of methane in the atmosphere over the East Siberian shelf: Is there any sign of methane leakage from shallow shelf hydrates?, Geophys. Res. Abstr., 10, EGU2008-A-01526.

Shakhova, N., I. Semiletov, I. Leifer, A. Salyuk, P. Rekant, and D. Kosmach (2010a), Geochemical and geophysical evidence of methane release over the East Siberian Arctic Shelf, J. Geophys. Res., 115, C08007, doi:10.1029/2009JC005602.

Shakhova, N., I. Semiletov, A. Salyuk, V. Yusupov, D. Kosmach, and O. Gustafsson (2010b), Extensive methane venting to the atmosphere from sediments of the East Siberian Arctic Shelf, Science, 327, 1246-1250, doi:10.1126/science.1182221.

Shindell, D. T., et al. (2006), Multimodel simulations of carbon monoxide: Comparison with observations and projected near-future changes, J. Geophys. Res., 111, D19306, doi:10.1029/2006JD007100.

Solberg, S., Ø. Hov, A. Søvde, I. S. A. Isaksen, P. Coddeville, H. De Backer, C. Forster, Y. Orsolini, and K. Uhse (2008), European surface ozone in the extreme summer 2003, J. Geophys. Res., 113, D07307, doi:10.1029/ 2007JD009098.

Soloviev, V. A., G. D. Ginzburg, E. V. Telepnev, and Y. N. Mikhaluk (1987), Cryothermia and gas hydrates in the Arctic Ocean, 150 pp., Sevmorgeologia, Leningrad, Russia.

Søvde, O. A., M. Gauss, S. P. Smyshlyaev, and I. S. A. Isaksen (2008), Evaluation of the chemical transport model Oslo CTM2 with focus on Arctic winter ozone depletion, J. Geophys. Res., 113, D09304, doi:10.1029/ 2007JD009240.

Tarnocai, C., J. G. Canadell, E. A. G. Schuur, P. Kuhry, G. Mazhitova, and S. Zimov (2009), Soil organic carbon pools in the northern circumpolar permafrost region, Global Biogeochem. Cycles, 23, GB2023, doi:10.1029/2008GB003327. 
Walter, K. M., S. A. Zimov, J. P. Chanton, D. Verbyla, and F. S. Chapin (2006), Methane bubbling from Siberian thaw lakes as a positive feedback to climate warming, Nature, 443(7107), 71-75, doi:10.1038/ nature 05040 .

Walter, K. M., L. C. Smith, and F. S. Chapin (2007), Methane bubbling from northern lakes: Present and future contributions to the global methane budget, Philos. Trans. R. Soc. A, 365(1856), 1657-1676.

Westbrook, G. K., et al. (2009), Escape of methane gas from the seabed along the West Spitsbergen continental margin, Geophys. Res. Lett. 36, L15608, doi:10.1029/2009GL039191.

Wickland, K. P., R. G. Striegl, J. C. Neff, and T. Sachs (2006), Effects of permafrost melting on $\mathrm{CO}_{2}$ and $\mathrm{CH}_{4}$ exchange of a poorly drained black spruce lowland, J. Geophys. Res., 111, G02011, doi:10.1029/ 2005JG000099.

WMO (2003), Scientific Assessment of Ozone Depletion: 2002, Global Ozone Research and Monitoring Project, report, 498 pp., Geneva.
Zimov, S. A., Y. V. Voropaev, I. P. Semiletov, S. P. Davidov, S. F. Prosiannikov, F. S. Chapin, M. C. Chapin, S. Trumbore, and S. Tyler (1997), North Siberian lakes: A methane source fueled by Pleistocene carbon, Science, 277(5327), 800-802, doi:10.1126/science.277.5327.800.

M. Gauss, Norwegian Meteorological Institute, N-0313 Oslo, Norway. I. S. A. Isaksen, Department of Geosciences, University of Oslo, N-0315 Oslo, Norway. (i.s.a.isaksen@geo.uio.no)

G. Myhre, CICERO, N-0318 Oslo, Norway.

C. Ruppel, U.S. Geological Survey, Woods Hole, MA 02543, USA.

K. M. Walter Anthony, Water and Environmental Research Center, Institute of Northern Engineering and International Arctic Research, University of Alaska, Fairbanks, AK 99775, USA. 